\title{
Opposite but analogous effects of road density on songbirds with contrasting habitat preferences
}

\author{
L. K. Butler ${ }^{1}$, L. Ries ${ }^{2}$, I.-A. Bisson ${ }^{3 *}$, T. J. Hayden ${ }^{4}$, M. M. Wikelski ${ }^{3 * *} \&$ L. M. Romero \\ 1 Department of Biology, The College of New Jersey, Ewing, NJ 08628, USA \\ 2 Department of Biology, University of Maryland, College Park, MD, USA \\ 3 Department of Ecology and Evolutionary Biology, Princeton University, Princeton, NJ, USA \\ 4 Engineer Research and Development Center, Champaign, IL, USA
}

\section{Keywords}

edge effects; glucocorticoids; habitat fragmentation; roads; stress.

\section{Correspondence}

Luke K. Butler, Department of Biology, The College of New Jersey, 2000 Pennington

Road, Ewing, NJ 08628-0718, USA. Tel: +1609 771 2531; Fax: +16096375118 Email: Ibutler@tcnj.edu
*Current address: Migratory Bird Center, Smithsonian Conservation Biology Institute, National Zoological Park, PO Box 37012, Washington, DC 20013, USA.

** Current address: Max Planck Institute for Ornithology, Vogelwarte Radolfzell, Schlossallee 2, 78315 Radolfzell, Germany.

\begin{abstract}
Roads are a widespread and growing form of habitat alteration, making their effects on wildlife a major conservation concern. We investigated effects of roads on occupancy patterns and stress physiology of the golden-cheeked warbler Setophaga chrysoparia, an endangered songbird that depends on large tracts of old-growth forest for breeding. We compared those effects in the white-eyed vireo Vireo griseus, a common songbird that prefers to breed in scrubby habitat that is common along forest roads. In warblers, older, socially dominant males were more likely to occupy territories, but had higher baseline plasma concentrations of corticosterone, in less-roaded habitats. In vireos, older males were equally likely to occupy territories, but, opposite to warblers, had lower baseline corticosterone concentrations, in less-roaded habitats. In both species, the corticosterone response to acute stress was unrelated to road density, and body condition and fat stores either increased or were sustained across road density groups during the breeding season, suggesting that breeding near roads did not cause chronic stress. Our results suggest that roads can cause increased male-male competition for territories in nearby roadless habitat, and may result in higher corticosterone concentrations in dominant individuals defending preferred sites near or far from edge, depending on species habitat preferences. Increased competition and chronically elevated corticosterone levels may be of concern if they alter parental care or immunity of individuals breeding in the best habitat.
\end{abstract}

\section{Introduction}

Many migratory songbird populations have declined in recent decades, particularly in species that breed in forests of North America (Robinson \& Wilcove, 1994; Sauer, Hines \& Fallon, 2007). These populations are known or are likely to be affected by habitat loss and edge effects (Paton, 1994; Donovan et al., 1997; Hartley \& Hunter, 1998; Ries et al., 2004). Because of their shape, roads can increase edge dramatically with only a small reduction in habitat. Thus, examining edge effects of roads could be a useful way to decouple effects of fragmentation from effects of habitat loss (Fahrig, 2003). However, because roads are associated with mortality because of vehicle strikes (Ries, Debinski \& Wieland, 2001) and disturbance from vehicle noise (Reijnen \& Foppen, 2006), roads may create multiple disturbances not associated with other forms of fragmentation. Here, we investigated effects of an isolated, traffic-free road network, in otherwise high-quality habitat, in order to examine impacts on songbirds due to extensive fragmentation that was largely uncoupled from habitat loss and human activity.

Habitat fragmentation has complex effects on songbird habitat occupancy (Mazerolle \& Hobson, 2002). In many songbirds, male-male competition for breeding territories results in younger, subordinate males occupying lesspreferred habitat, and older, dominant males occupying better habitat (Krebs, 1971; Sherry \& Holmes, 1989; Hatchwell, Chamberlain \& Perrins, 1996; Holmes, Marra \& Sherry, 1996; Petit \& Petit, 1996). Male songbirds often attempt to upgrade territories within and between breeding seasons (Krebs, 1971; Sherry \& Holmes, 1989; Bayne \& 
Hobson, 2001), putting competitive pressure on males defending preferred sites (Mazerolle \& Hobson, 2002). Therefore a species preference for breeding near or far from edges could drive spatial variation in male-male competition within a road-fragmented landscape, resulting in age- and size-based occupancy patterns and increased competitive pressure on territorial males in the best habitat (Holmes et al., 1996; Petit \& Petit, 1996; Mazerolle \& Hobson, 2002).

Hormonal measures of stress offer a potentially useful way to detect harmful but sublethal effects of habitat alteration on individual animals (Romero, 2004; Cockrem, 2005). Under normal conditions, corticosterone circulates in the blood at a relatively low level and plays a major role in homeostasis (Sapolsky, Romero \& Munck, 2000). Concentrations increase within minutes of perception of a threat, with several effects that are thought to help an animal cope and recover (Sapolsky et al., 2000; Wingfield \& Romero, 2001). Perhaps paradoxically, experimentally induced 'chronic' stress, lasting several days, results in lower - not higher - baseline glucocorticoid concentrations, and a damped glucocorticoid response to an acute stressor (Rich \& Romero, 2005; Cyr \& Romero, 2007; Dickens, Earle \& Romero, 2009). However, naturally occurring chronic stress can result in increased or decreased glucocorticoid concentrations (Busch \& Hayward, 2009).

We compared effects of roads on age-based occupancy patterns, corticosterone concentrations, and body condition of two migratory songbirds breeding in Texas, USA. The endangered golden-cheeked warbler Setophaga chrysoparia prefers to nest in large patches ( 100 ha) of mature juniperoak Juniperus spp.-Quercus spp. woodland (Ladd \& Gass, 1999). Within heavily wooded landscapes, habitat fragmentation is not a strong predictor of occurrence (Magness, Wilkins \& Hejl, 2006), but roads-based fragmentation increases warbler nest predation (Peak, 2007). Therefore, warblers may prefer territories in less-roaded forest. In contrast, the common white-eyed vireo Vireo gilvus, prefers to breed in dense low shrubs with an open canopy (Conner et al., 1983), characteristic of heavily roaded habitat at our site. We used these contrasting habitat preferences to make species-specific predictions about how roads would affect males during the breeding season.

In warblers, we predicted that younger, subordinate males would be excluded from territories in contiguous forest and more likely to occupy territories near roads. We also predicted that warblers breeding near roads would be in worse physical condition (as indexed by body mass and body fat stores), and have increased (or decreased; see earlier) baseline corticosterone concentrations compared with warblers breeding in contiguous forest. We predicted opposite patterns in vireos: a higher proportion of young males, and males in worse physiological condition, in contiguous forest. We expected a damped corticosterone response to the acute stress of capture and handling in warblers from roaded habitat and vireos from contiguous habitat.

\section{Methods}

\section{Study area}

Work was conducted at Fort Hood, Texas, USA $\left(31^{\circ} 08^{\prime} \mathrm{N}\right.$, $\left.97^{\circ} 46^{\prime} \mathrm{W}\right)$. Most of the roads and trails transecting our sites were unimproved and unpaved. Work was conducted on parts of the installation where military activity was either prohibited (31\% of sample points) or obstructed, or very rare and detected only a few times during the study. Thus, this study reports road effects that are largely independent of human activity.

\section{Study species}

Warbler nest-building peaks in early April, with a mean egg-laying date of 17 April (Ladd \& Gass, 1999). Warblers switch from breeding to molting in mid-June (LKB, unpubl. data). Vireo nesting peaks slightly later (early egg date 12 April in Texas; Hopp, Kirby \& Boone, 1995), and adults switch from breeding to molt in early July (Butler, Hayden \& Romero, 2008)

\section{Defining road density groups}

We used remotely sensed imagery to establish four categories of target sample points, along each of ten separate bird sampling routes, and representing a range of common road densities within Fort Hood: Zero (no roads or trails wider than $3 \mathrm{~m}$ within $100 \mathrm{~m}$ of the capture site), Low (one relatively straight trail, 3-5 $\mathrm{m}$ wide, near the capture point), Medium (the intersection of two to three 3-5 m width trails), and High (the intersection of several trails and roads; Fig 1a). A handheld global positioning system (Explorist II, Garmin, Inc.) was used to locate targeted sites in the field, but occasionally sites were moved slightly due to inaccessibility or to place nets for capturing the target bird. A total of 75 capture sites (seven to nine per sampling route) were used to capture 51 male golden-cheeked warblers from 6 April to 29 May, and 45 male white-eyed vireos from 21 April to 4 June, in 2008. Road density groups differed significantly in percent canopy gap (road density group: $F_{3,86}=64.6$, $P<0.0001$, and all pair-wise Fisher's protected least significant difference (PLSD) $P<0.05$; Fig. 1b) and total $\mathrm{m}$ of road (road density group: $F_{3,86}=145.5, P<0.0001$, and all pair-wise Fisher's PLSD $P<0.01$; Fig. 1c). Each species occupied the four road density categories with similarly high frequency (82-100\%; see Supporting Information).

\section{Capture of focal animals}

Birds were lured into mist nets by playing conspecific vocalizations recorded at Fort Hood. We monitored the net continuously and sampled the first male captured. In most cases, this male was singing (a clear sign of territory ownership) nearby before capture, and no other male sang in the immediate area before or after capture of the first male. 
(a)

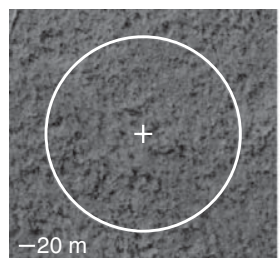

(b)
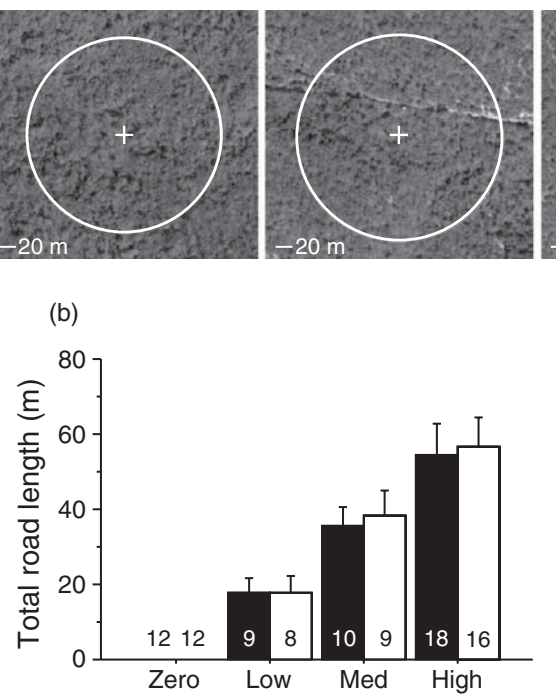

,
Medium

120

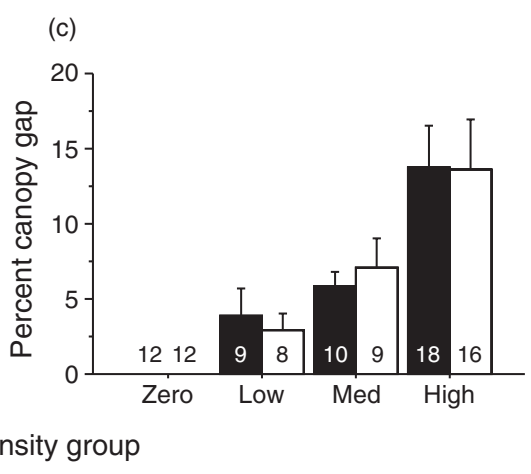

High

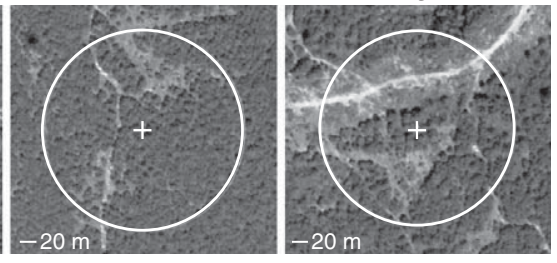

Figure 1 (a) Aerial images of four road density categories as defined by the length and width of roads within $100 \mathrm{~m}$ (open white circle) of the sample point (+). Dark gray areas represent juniper forest (goldencheeked warbler Setophaga chrysoparia habitat), medium gray areas represent grasses and shrubs, and light gray areas represent bare ground. (b) Total road and trail length [mean $\pm 95 \%$ confidence interval (Cl) ] and (c) percent canopy gap (mean $\pm 95 \% \mathrm{Cl}$ ) among the sites where golden-cheeked warblers (filled bars) and white-eyed vireos Vireo gilvus (open bars) were sampled. Sample sizes shown above $x$ axis.

\section{Sampling and hormone assays}

The first blood sample was taken $\leq 3$ min after capture. Corticosterone concentrations at the time of capture were unrelated to playback duration prior to capture [analysis of covariance (ANCOVA) with playback duration (logtransformed) as covariate, warblers, mean min \pm standard deviation $(\mathrm{SD})=8.9 \pm 10.1, F_{1,39}=0.9, P=0.36$; vireos, $\left.\left.7.7 \pm 8.9, F_{1,33}=0.7, P=0.41\right)\right]$, so these 'baseline' samples should reflect pre-capture corticosterone concentrations, and not a response to capture stress (Romero \& Romero, 2002; Romero \& Reed, 2005) or conspecific song playback (Fusani et al., 2005). A second blood sample was taken 30 min after capture to measure the acute stress response. All procedures were approved by the Institutional Animal Care and Use Committee at Tufts University.

Blood was sampled from 1 to $7 \mathrm{~h}$ after sunrise using methods described previously (Butler et al., 2009). Briefly, blood was taken from the alar vein, placed on ice in the field, and centrifuged within $24 \mathrm{~h}$. Plasma was then frozen until it was assayed at Tufts University. Plasma corticosterone was assayed using a standard radioimmunoassay (Wingfield, Vleck \& Moore, 1992; see Supporting Information).

Each bird was weighed using a 30-g Micro-Line spring scale (Pesola, Baar, Switzerland) graduated to $0.25 \mathrm{~g}$ (accuracy $\pm 0.3 \%$ ). Body fat was scored on a scale of 0 (no visible fat) to 5 (heavy sheets of fat) following Romero et al. (1997). As indices of overall body size, we measured tarsus length using a caliper (model SPI 2000, Swiss Precision Instruments, Garden Grove, CA, USA) and unflattened wing chord using a wing rule (Pyle, 1997). Age class was determined using plumage traits that distinguish birds in their first breeding season (hereafter 'young' birds) from older birds (Hopp et al., 1995; Pyle, 1997; Ladd \& Gass, 1999).
To control for any seasonal effects, we sampled each road category within each route over $1-5$ days in warblers (mean $\pm \mathrm{SD}=3.1 \pm 1.3, n=9$; exception noted later) and 3-8 days in vireos (mean $\pm \mathrm{SD}=3.4 \pm 1.8, n=10$ ). In one additional warbler route, five of six samples were obtained over a 3-day period and one high road density sample was obtained 3 weeks earlier.

\section{Statistics}

Demographic parameters were analyzed using chi-squared and Mann-Whitney tests (Zar, 1999). Corticosterone concentrations did not violate the assumption of homogeneity of variance (in Levene's test, all $P>0.05$; Zar, 1999), so we compared corticosterone among road groups using ANCOVA and Fisher's PLSD tests. Body condition was analyzed by treating body mass as the dependent variable in an ANCOVA, with road density group as the independent variable and tarsus length and day of year as covariates (García-Berthou, 2001; residuals of body mass regressed on tarsus length are presented graphically). Body fat and body size were analyzed in analyses of variance (ANOVAs). No young warbler was captured at a low-roads site $(n=9$ males captured) and only two were captured at zero-roads sites $(n=13)$, precluding statistical analysis of age effects on warbler physiology. Age was not a significant factor in any analysis of vireo physiology (all $P>0.15$ ), so it was removed from the model. We included day of year as a covariate in all ANCOVAs initially, and removed it if it had no significant main effects or interactions. We analyzed corticosterone separately within early and late stages of the breeding season in order to account for potential seasonal effects (Romero, 2002). 


\section{Results}

\section{Demographic correlates of road density}

\section{Warblers}

Occupancy by young male warblers did not vary significantly among the four road categories $\left[\chi^{2}=5.4\right.$, degrees of freedom $(\mathrm{df})=3, P=0.15$; Table 1]; however, young males were nearly fourfold more common than older males at medium- and high-roads sites (35\% of 29 males) compared with the Low- and Zero-roads sites ( $9 \%$ of 22 males), and this two-group contrast was statistically significant $\left(\chi^{2}=4.5\right.$, $\mathrm{df}=1, P=0.034$; Table 1). Body size, as indexed by tarsus length and wing chord, was unrelated to site occupancy (each $P>0.5$ ).

\section{Vireos}

In contrast to warblers, vireos showed no significant relationship between road density and young male occupancy

Table 1 Patterns of territory occupancy by young male goldencheeked warblers and young male white-eyed vireos in relation to road density in the surrounding habitat

\begin{tabular}{lcccc}
\hline & \multicolumn{4}{c}{$\begin{array}{c}\text { \% young males } \\
\text { road density group }\end{array}$} \\
\cline { 2 - 5 } \multicolumn{1}{c}{ Species } & Zero & Low & Medium & High \\
\hline Golden-cheeked warbler & 15 & 0 & 30 & 37 \\
$(n)$ & $(13)$ & $(9)$ & $(10)$ & $(19)$ \\
White-eyed vireo & 33 & 38 & 56 & 31 \\
$(n)$ & $(12)$ & $(8)$ & $(9)$ & $(16)$ \\
\hline
\end{tabular}

rate $\left(\chi^{2}=1.6, \mathrm{df}=3, P=0.66\right.$; Table 1$)$. As in warblers, vireo body size indices were unrelated to site occupancy (each $P>0.2$ ).

\section{Physiological Correlates of Road Density}

\section{Warblers}

Baseline total corticosterone concentrations varied significantly among road groups in warblers $\left(F_{3,42}=4.3, P=0.01\right.$, Fig. 2a), with medium- and high-roads males having significantly lower concentrations than zero-roads males (Fisher's PSLD tests, $P=0.003$ and $P=0.005$, respectively). Concentrations in low-roads males were intermediate (Fig. 2a). This result was not attributable to the low concentrations in young males at medium- and high-roads sites (Fig. 2a), as the same result obtained when the analysis was limited to older males $\left(F_{3,31}=2.9, P=0.049\right.$, Fisher's PSLD tests, $P=0.02$ and $P=0.02$, respectively).

Road-related differences in baseline corticosterone appeared to emerge late in the warbler breeding season (Fig. 3a). Early in the breeding season (prior to the median male capture date of 23 April), baseline corticosterone concentrations in older males were similar among road categories $\left(F_{3,12}=1.4, P=0.29\right)$, but later in the breeding season, concentrations in older males varied significantly among road groups $\left(F_{3,15}=3.8, P=0.034\right)$, with High-roads males having significantly lower concentrations than zero-roads males (Fisher's PSLD tests, $P=0.005$ ).

Warblers responded to $30 \mathrm{~min}$ of capture stress with large increases in corticosterone (in repeated measures ANOVA of baseline and 30-min samples, $P<0.0001$; Fig. 2c). However, this response was unrelated to road group $\left(F_{3,41}=0.2, P=0.88\right)$.

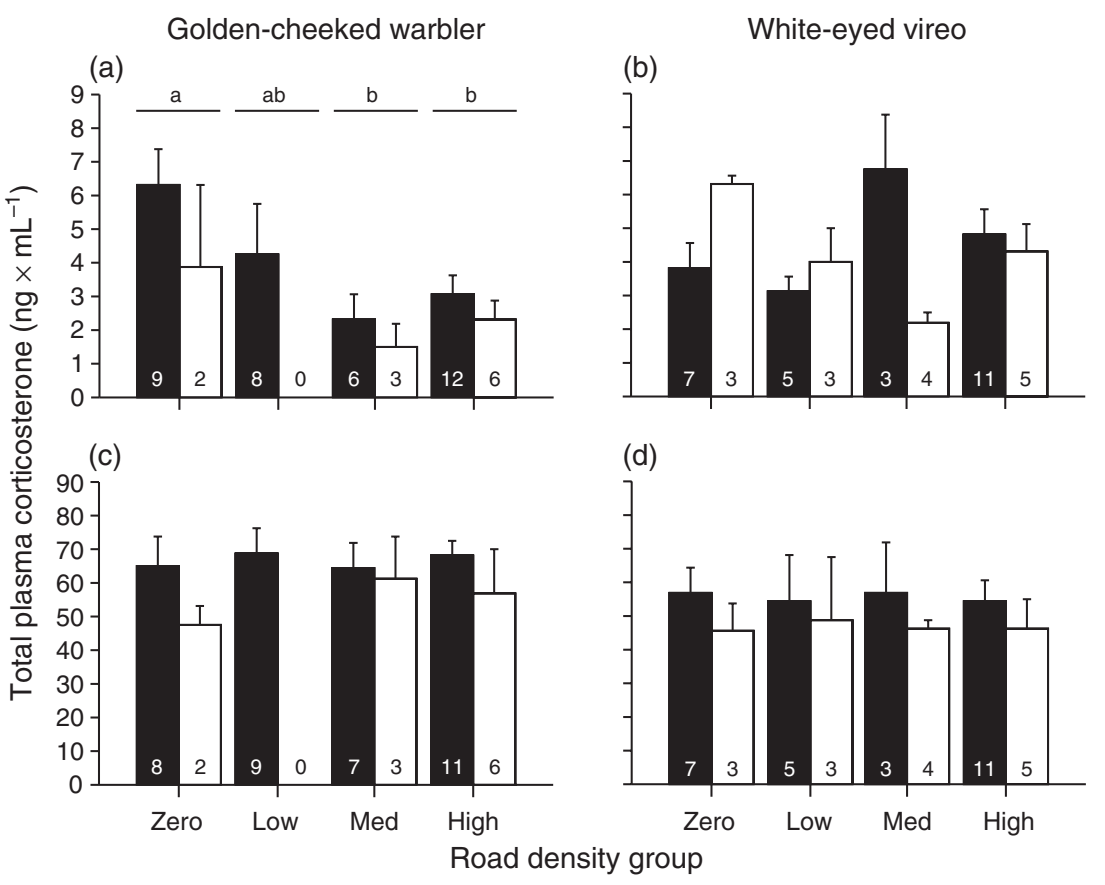

Figure 2 Plasma corticosterone concentrations (mean \pm standard error) in first-year (open bar) and older (filled bar) male $(a, c)$ golden-cheeked warblers Setophaga chrysoparia and (b, d) white-eyed vireos Vireo gilvus according to road density in the surrounding habitat. Blood was sampled $(a, b)$ within $3 \mathrm{~min}$ of capture and (c, d) $30 \mathrm{~min}$ after capture. In (a), road groups that share the same letter are not significantly different. Sample sizes shown above $x$ axis. 


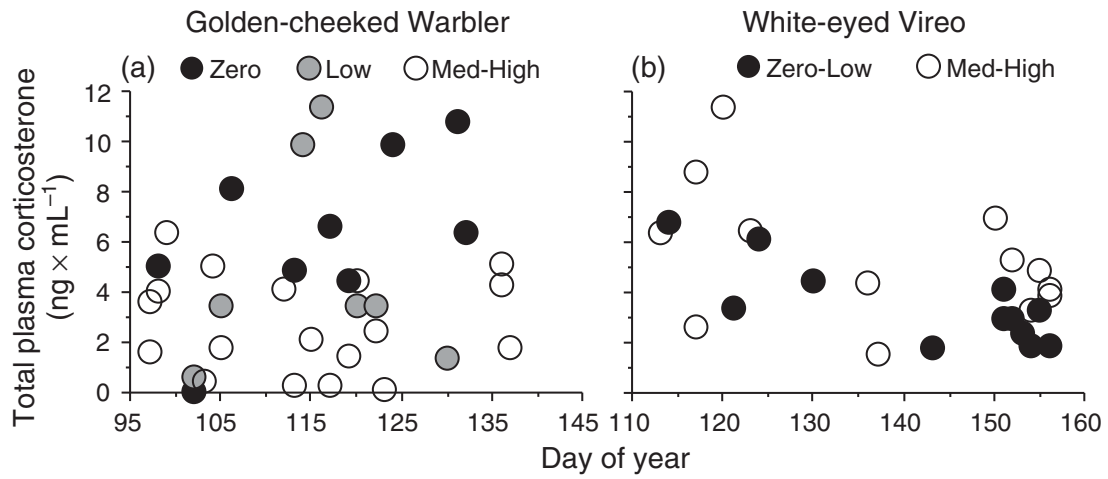

(a)

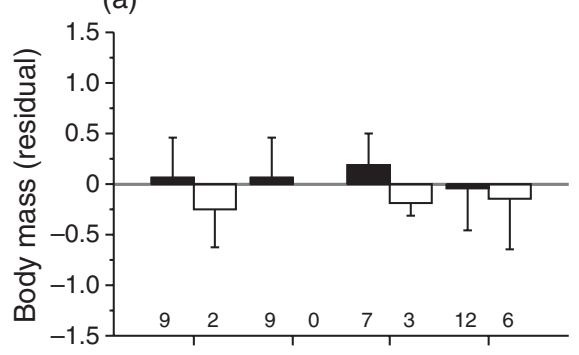

(c)

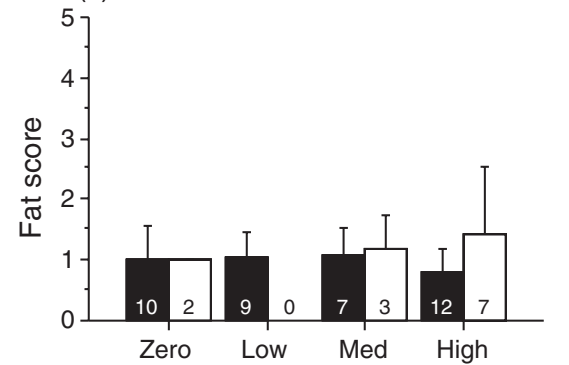

(b)

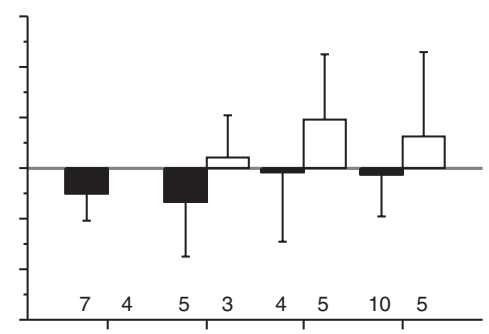

(d)

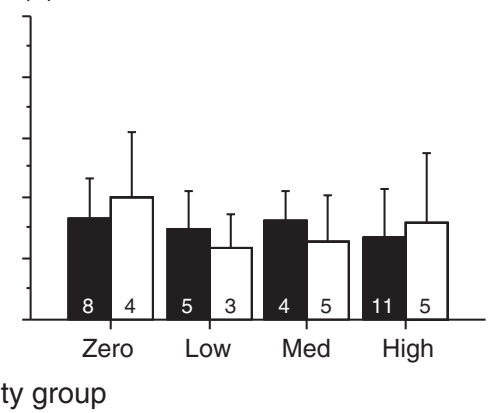

Figure 3 Plasma corticosterone concentrations of older male (a) golden-cheeked warblers Setophaga chrysoparia and (b) white-eyed vireos Vireo gilvus according to day of year and road density group (some groups pooled if not significantly different from each other).
Figure 4 (a, b) Residual body mass [mean \pm standard deviation (SD) ] and (c, d) body fat score (mean $\pm S D$ ) in first-year (open bar) and older (filled bar) male $(\mathrm{a}, \mathrm{c}$ ) golden-cheeked warblers Setophaga chrysoparia and (b, d) white-eyed vireos Vireo gilvus according to road density in the surrounding habitat. Sample sizes shown above $x$ axis.
Body mass and fat score were similar across road groups in warblers (body mass, $F_{3,41}=1.4, P=0.26$; fat score, $F_{3,42}=2.2, P=0.11$; Fig. 4 a,c). Fat score increased significantly with day of year $\left(F_{1,42}=10.5, P=0.002\right.$; data not shown), but similarly across road groups (interaction term road group $\times$ day of year, $F_{3,42}=2.15, P=0.11$ ). Body mass was unrelated to corticosterone concentrations in warblers (all $P>0.1$ ).

\section{Vireos}

Baseline corticosterone concentrations were similar in vireos among all four road groups $\left(F_{3,35}=1.6, P=0.21\right.$, Fig. 2b), although, analogous but opposite to warblers, in a two-group contrast baseline concentrations in vireos were significantly higher in older males captured at medium- and high-roads sites than at zero- and low-roads sites $\left(F_{1,23}=4.5\right.$,
$P=0.045)$, and, as in warblers, this contrast emerged later in the breeding season. Prior to the median male capture date of 29 May, baseline corticosterone concentrations were similar between males captured at zero-/low-roads sites and medium-/high-roads sites $\left(F_{1,10}=0.7, P=0.4\right)$, but significantly different after this date $\left(F_{1,11}=10.8, \quad P=0.007\right.$; Fig. 3b).

Capture stress caused large increases in vireo corticosterone across road groups (in repeated measures ANOVA of baseline and 30-min samples, $P<0.0001$; Fig. 2d). However, this response was unrelated to road density $\left(F_{3,37}=0.1, P=0.99\right)$.

Body mass and fat score were unrelated to road density (body mass, $F_{3,36}=2.1, P=0.12$; fat score, $F_{3,41}=0.62$, $P=0.61$; Fig $4 \mathrm{~b}, \mathrm{~d}$ ) or day of year (each $P>0.2$ ), similar to warblers. Body mass was negatively correlated with 30-min concentrations in vireos $\left(r=-0.31, F_{1,38}=4.1, P=0.049\right.$; data not shown). 


\section{Discussion}

\section{Demographic consequences of fragmentation by roads}

Our results agree with other studies of migratory New World warblers showing that older males exclude younger males from preferred habitats (Sherry \& Holmes, 1989; Holmes et al., 1996; Harris \& Reed, 2002). However, ours is the first study we know of to demonstrate age-related segregation in a bird based on road density. Older male goldencheeked warblers were significantly more likely than young male warblers to occupy sites with lower road densities, and this segregation appeared to be most extreme early in the breeding season when opportunities to attract a mate were still available. The only two young males captured at zeroor low-roads sites were captured on 30 April and 17 May, long after arrival, territory establishment, and peak nesting ( $n=13$ males captured at zero- and low-roads sites 6-29 April). These two young males may have been replacements that moved into the zero-roads habitat after territory owners died or abandoned a territory.

In contrast, we found no age-based habitat segregation in vireos, and young males were common at the medium- and high-roads (shrubby) sites early in the breeding season (36\% of 11 males captured during the first 2 weeks of sampling, 21 April-5 May). Habitats within our range of road densities may have been equally preferable to dominant male vireos, or, unlike warblers, there may be no age-based dominance hierarchy in vireos. Unfortunately, the breeding system of white-eyed vireos is not well-studied, but first-year males are known to hold territories and attract mates (Hopp et al., 1995; LKB \& TJH).

\section{Physiological consequences of fragmentation by roads}

Golden-cheeked warblers had lower baseline corticosterone concentrations in more heavily roaded habitat than in roadless habitat. There are three possible explanations for this contrast: corticosterone was suppressed in males in heavily roaded habitat, or elevated in males in contiguous habitat, or both may have occurred.

Although low corticosterone concentrations in warblers from heavily roaded habitats could potentially result from chronic stress, we doubt this explanation. When chronic stress is induced experimentally in birds, the result is suppression of baseline corticosterone (Rich \& Romero, 2005; Walker, Boersma \& Wingfield, 2006; Cyr \& Romero, 2007; Dickens et al., 2009). However, when corticosterone concentrations are correlated with environmental conditions thought to cause chronic stress (e.g., low quality or disturbed habitat), the results are inconsistent: some studies show decreased baseline corticosterone (e.g., Homan et al., 2003), but others show increased baseline corticosterone (e.g., Marra \& Holberton, 1998). It is tempting to conclude that the low corticosterone concentrations found in warblers from heavily roaded sites are analogous to the low concentrations found in experimentally chronically stressed birds, but our other physiological measures did not match those from experimentally induced chronic stress. Experimental chronic stress results in lower body condition (Rich \& Romero, 2005; Walker et al., 2006; Dickens et al., 2009) and a suppressed acute corticosterone response to stress (Romero \& Wikelski, 2002; Rich \& Romero, 2005; Dickens et al., 2009). However, in the current study, across road groups, warblers were in similar body condition, gained fat similarly during the breeding season, and responded with similarly large responses to capture stress, all suggesting that warblers near roads were not chronically stressed.

Similar reasoning applies to white-eyed vireos. Baseline corticosterone was significantly higher in medium- and high-roads sites among older male vireos, opposite to warblers, but analogous to warblers with respect to habitat preferences. Vireos also showed no road-related variation in body condition or the corticosterone response to acute stress, so we conclude that the lower baseline corticosterone concentrations in older male vireos in less-roaded habitat were not a result of chronic stress (Rich \& Romero, 2005).

To explain the demographic and physiological correlates of road density found in this study, we propose that, within a mature forest landscape, roads either degraded (warblers) or improved (vireos) habitat quality, increasing the intensity of local male-male competition far from (warblers) or near (vireos) roaded habitat, and causing an increase in baseline corticosterone concentrations in males defending roadless (warblers) or roaded (vireos) territories. This explanation is consistent with known habitat preferences for contiguous forest in warblers (Ladd \& Gass, 1999) and for open scrub in vireos (Conner et al., 1983). We found that older, dominant male warblers were more common in roadless sites, as in several other songbirds in which dominant males exclude subordinate males from preferred habitat (Sherry \& Holmes, 1989; Holmes et al., 1996; Petit \& Petit, 1996; Harris \& Reed, 2002). Although we found no evidence that male vireos assort according to an age-based dominance hierarchy, it is unlikely that less competitive, subordinate male vireos (old or young) hold preferred territories.

Additionally, in other seasonally breeding temperate songbirds, when males stop defending preferred territories (because of experimental or natural causes) they are rapidly replaced by non-territorial males (Bayne \& Hobson, 2001) or males defending suboptimal territories (e.g., Krebs, 1971; Beletsky \& Orians, 1987). Therefore, we expect that in this study males defending optimal habitat experienced greater intrusion pressure than males defending suboptimal habitat.

Finally, territorial threats are well-known to elicit hormonal responses in territory owners, including increased glucocorticoid concentrations (Wingfield et al., 1990; Silverin, 1993; Silverin, 1998a; van Duyse et al., 2004; Landys et al., 2007). A short-term increase in glucocorticoid concentrations improves response to a physical threat by augmenting stimulation of the cardiovascular system, activating the immune system, and mobilizing energy stores (Sapolsky 
et al., 2000). Similar to the current study, male pied flycatchers Ficedula hypoleuca breeding in preferred deciduous habitat had higher baseline corticosterone concentrations than males breeding in suboptimal coniferous forest, which was attributed to higher intrusion rates in preferred habitat (Silverin, 1998b).

In most birds, corticosterone concentrations reach an annual peak early in the breeding season and then decline (Romero, 2002). Therefore, the high late-season corticosterone concentrations in warblers and vireos from preferred habitats strongly suggest a response to an environmental stimulus. We doubt that the stimulus was increased energetic demands of nestling provisioning, because that stimulus does not increase baseline corticosterone in males of other temperate songbirds with similar paternal care [e.g., yellow warbler S. petechia (Wilson \& Holberton, 2004) and white-crowned sparrow Zonotrichia leucophrys (Bonier et al., 2007) ]. Greater foraging costs in interior habitat have been observed in another edge-sensitive bird, the northern spotted owl Strix occidentalis (Hayward et al., 2011), but this seems unlikely to explain elevated corticosterone concentrations in warblers from interior habitat in this study, because vireos and warblers have similar diets (Hopp et al., 1995; Ladd \& Gass, 1999), but vireos had lower corticosterone concentrations in interior habitat.

\section{Conclusions}

The ideas that anthropogenic habitat degradation can alter demographic patterns (e.g., Hatchwell et al., 1996) and glucocorticoid concentrations (e.g., Wasser et al., 1997) in birds are not new. However, ours is the first study we know of to suggest that roads alone, independent of habitat loss and human activity, can be the bases for these phenomena in songbirds. We found opposite, but analogous effects on two species breeding in the same landscape, strongly implicating road density as the cause of the patterns described here. This suggests that, for some species, edges change the quality of habitat in ways that differ from changes due to habitat loss or human activity. It also reiterates the finding that these responses are species-specific, and often tied to key habitat associations (Ries et al., 2004), although this study was limited to a two-species comparison.

Our study site at Fort Hood is considered a high-quality habitat for golden-cheeked warblers based on occupancy rates (Jetté, Hayden \& Cornelius, 1998) and reproductive success (Jetté et al., 1998; Peak, 2007). We found demographic and physiological consequences of roads at low densities ( $\sim 5-15 \%$ canopy gap), suggesting sensitivity of male warblers to this form of edge. Elevated glucocorticoids may help dominant males maintain territories in optimal habitat, but they may also have negative long-term effects on the immune system (Sapolsky et al., 2000), parental care (Silverin, 1986) and molt dynamics (Romero, Strochlic \& Wingfield, 2005; Busch et al., 2008). Consequently, although roads did not elicit symptoms of chronic stress, observed changes in occupancy patterns and baseline corticosterone concentrations indicate that habitat quality was degraded near traffic-free roads, and could potentially compromise an individual bird's ability to cope with subsequent challenges.

\section{Acknowledgements}

Funding was provided by the Strategic Environmental Research and Development Program (SI-1396 and SI-1597), but does not necessarily reflect the position or views of the US government. Roads and trails were digitized by $\mathrm{A}$. Doherty. Imagery was received from M. Noble of The Nature Conservancy at Ft. Hood. E. Gill made distinguished contributions to the field work. L. Glassman, J. Ferrer, M. Vinson, and A. Whitley also assisted with field experiments. M. Dickens and N. Cyr assisted with assays, and J. Reed assisted with statistics. Two anonymous reviewers made suggestions that improved the manuscript.

\section{References}

Bayne, E.M. \& Hobson, K.A. (2001). Effects of habitat fragmentation on pairing success of Ovenbirds: importance of male age and floater behavior. Auk 118, 380388.

Beletsky, L.D. \& Orians, G.H. (1987). Territoriality among male red-winged blackbirds. Behav. Ecol. Sociobiol. 20, 21-34.

Bonier, F., Martin, P.R., Sheldon, K.S., Jensen, J.P., Foltz, S.L. \& Wingfield, J.C. (2007). Sex-specific consequences of life in the city. Behav. Ecol. 18, 121-129.

Busch, D.S. \& Hayward, L.S. (2009). Stress in a conservation context: a discussion of glucocorticoid actions and how levels change with conservation-relevant variables. Biol. Conserv. 142, 2844-2853.

Busch, D.S., Sperry, T.S., Peterson, E., Do, C.-T., Wingfield, J.C. \& Boyd, E.H. (2008). Impacts of frequent, acute pulses of corticosterone on condition and behavior of Gambel's white-crowned sparrow (Zonotrichia leucophrys gambelii). Gen. Comp. Endocrinol. 158, 224-233.

Butler, L.K., Bisson, I.-A., Hayden, T.J., Wikelski, M. \& Romero, L.M. (2009). Adrenocortical responses to offspring-directed threats in two open-nesting birds. Gen. Comp. Endocrinol. 162, 313-318.

Butler, L.K., Hayden, T.J. \& Romero, L.M. (2008). Prebasic molt of black-capped and white-eyed vireos: effects of breeding site and the El Niño-Southern Oscillation. Condor 110, 428-440.

Cockrem, J.F. (2005). Conservation and behavioral neuroendocrinology. Horm. Behav. 48, 492-501.

Conner, R.N., Dickson, J.G., Locke, B.A. \& Segelquist, C.A. (1983). Vegetation characteristics important to common songbirds in east Texas. Wilson Bull. 95, 349361.

Cyr, N. \& Romero, L.M. (2007). Chronic stress in freeliving European starlings reduces corticosterone concentrations and reproductive success. Gen. Comp.

Endocrinol. 151, 82-89. 
Dickens, M.J., Earle, K.A. \& Romero, L.M. (2009). Initial transference of wild birds to captivity alters stress physiology. Gen. Comp. Endocrinol. 160, 76-83.

Donovan, T.M., Jones, P.W., Annand, E.M. \& Thompson, F.R. III (1997). Variation in local-scale edge effects: mechanisms and landscape context. Ecology 78, 2064 2075.

van Duyse, E., Pinxten, R., Darras, V.M., Arckens, L. \& Eens, M. (2004). Opposite changes in plasma testosterone and corticosterone levels following a simulated territorial challenge in great tits. Behavior 141, 451-467.

Fahrig, L. (2003). Effects of habitat fragmentation on biodiversity. Annu. Rev. Ecol. Syst. 34, 487-515.

Fusani, L., Canoine, V., Goymann, W., Wikelski, M. \& Hau, M. (2005). Difficulties and special issues associated with field research in behavioral neuroendocrinology. Horm. Behav. 48, 484-491.

García-Berthou, E. (2001). On the misuse of residuals in ecology: testing regression residuals vs. the analysis of covariance. J. Anim. Ecol. 70, 708-711.

Harris, R.J. \& Reed, J.M. (2002). Effects of forest-clearcut edges on a forest-breeding songbird. Can. J. Zool. 80, 1026-1037.

Hartley, M.J. \& Hunter, M.L. (1998). A meta-analysis of forest cover, edge effects, and artificial nest predation rates. Conserv. Biol. 12, 465-469.

Hatchwell, B.J., Chamberlain, D.E. \& Perrins, C.M. (1996). The demography of blackbirds Turdus merula in rural habitats: is farmland a sub-optimal habitat? J. Appl. Ecol. 33, 1114-1124.

Hayward, L.S., Bowles, A.E., Ha, J.C. \& Wasser, S.K. (2011). Impacts of acute long-term vehicle exposure on physiology and reproductive success of the northern spotted owl. Ecosphere 2, 1-20.

Holmes, R.T., Marra, P.P. \& Sherry, T.W. (1996). Habitatspecific demography of breeding black-throated blue warblers (Dendroica caerulescens): implications for population dynamics. J. Anim. Ecol. 65, 183-195.

Homan, R.N., Regosin, J.V., Rodrigues, D.M., Reed, J.M., Windmiller, B.S. \& Romero, L.M. (2003). Impacts of varying habitat quality on the physiological stress of spotted salamanders (Ambystoma maculatum). Anim. Conserv. 6, 11-18.

Hopp, S.L., Kirby, A. \& Boone, C.A. (1995). White-eyed Vireo (Vireo Griseus), The Birds of North America Online. Poole, A. (Ed.). Philadelphia: The Academy of Natural Sciences and Washington, DC: The American Ornithologists' Union. [WWW document]. Available at http://bna.birds.cornell.edu/bna/species/168 (February 2012).

Jetté, L.A., Hayden, T.J. \& Cornelius, J.D. (1998). Demographics of the Golden-cheeked Warbler (Dendroica chrysoparia) on Fort Hood, Texas. USA CERL Technical Report 98/52. Champaign, IL: U.S. Army Corps of Engineers Construction Engineering Research Laboratory.
Krebs, J.R. (1971). Territory and breeding density in the great tit, Parus major L. Ecology 52, 2-22.

Ladd, C. \& Gass, L. (1999). Golden-cheeked Warbler (Dendroica chrysoparia), The Birds of North America Online. Poole, A. (Ed.). Philadelphia: The Academy of Natural Sciences and Washington, DC: The American Ornithologists' Union. [WWW document]. Available at http:// bna.birds.cornell.edu/bna/species/420 (February 2012).

Landys, M.M., Goymann, W., Raess, M. \& Slagsvold, T. (2007). Hormonal responses to male-male social challenge in the blue tit Cyanistes caeruleus: singlebroodedness as an explanatory variable. Physiol. Biochem. Zool. 80, 228-240.

Magness, D.R., Wilkins, R.N. \& Hejl, S.J. (2006). Quantitative relationships among golden-cheeked warbler occurrence and landscape size, composition, and structure. Wildl. Soc. Bull. 34, 473-479.

Marra, P.P. \& Holberton, R.L. (1998). Corticosterone levels as indicators of habitat quality: effects of habitat segregation in a migratory bird during the non-breeding season. Oecologia 116, 284-292.

Mazerolle, D.F. \& Hobson, K.A. (2002). Territory size and overlap in male ovenbirds: contrasting a fragmented and contiguous boreal forest. Can. J. Zool. 82, 17741781.

Paton, P.W.C. (1994). The effect of edge on avian nest success - how strong is the evidence? Conserv. Biol. 8, 17-26.

Peak, R.G. (2007). Forest edges negatively affect goldencheeked warbler nest survival. Condor 109, 628-637.

Petit, L.J. \& Petit, D.R. (1996). Factors governing habitat selection by prothonotary warblers: field tests of the Fretwell-Lucas models. Ecol. Monogr. 66, 367-387.

Pyle, P. (1997). Identification guide to North American birds. Part I. Bolinas, CA: Slate Creek Press.

Reijnen, R. \& Foppen, R. (2006). Impact of road traffic on breeding bird populations. Environ. Pollut. 10, 255-274.

Rich, E.L. \& Romero, L.M. (2005). Exposure to chronic stress downregulates corticosterone responses to acute stressors. Am. J. Physiol. 288, R1628-R1636.

Ries, L.R., Debinski, D.M. \& Wieland, M.L. (2001). Conservation value of roadside prairie restoration to butterfly communities. Conserv. Biol. 15, 401-411.

Ries, L.R., Fletcher, R.J., Jr, Battin, J. \& Sisk, T.D. (2004). Ecological responses to habitat edges: mechanisms, models, and variability explained. Annu. Rev. Ecol. Evol. Syst. 35, 491-522.

Robinson, S.K. \& Wilcove, D.S. (1994). Forest fragmentation in the temperate zone and its effects on migratory songbirds. Bird Conserv. Intern. 4, 233-249.

Romero, L.M. (2002). Seasonal changes in plasma glucocorticoid concentrations in free living vertebrates. Gen. Comp. Endocrinol. 128, 1-24. 
Romero, L.M. (2004). Physiological stress in ecology: lessons from biomedical research. Trends Ecol. Evol. 19, 249-255.

Romero, L.M. \& Reed, J.M. (2005). Collecting baseline corticosterone samples in the field: is under three minutes good enough? Comp. Biochem. Physiol. A Physiol. 140, 73-79.

Romero, L.M. \& Romero, R.C. (2002). Corticosterone responses in wild birds: the importance of rapid initial sampling. Condor 104, 129-135.

Romero, L.M., Soma, K.K., O’Reilly, K.M., Suydam, R. \& Wingfield, J.C. (1997). Territorial behavior, hormonal changes, and body condition in an Arctic-breeding song bird, the redpoll (Carduelis flammea). Behavior 134, 727 747.

Romero, L.M., Strochlic, D. \& Wingfield, J.C. (2005). Corticosterone inhibits feather growth: potential mechanism explaining seasonal down regulation of corticosterone during molt. Comp. Biochem. Physiol. 142A, 65-73.

Romero, L.M. \& Wikelski, M. (2002). Exposure to tourism reduces stress-induced corticosterone levels in Galápagos marine iguanas. Biol. Conserv. 108, 371-374.

Sapolsky, R.M., Romero, L.M. \& Munck, A.U. (2000). How do glucocorticoids influence stress-responses? Integrating permissive, suppressive, stimulatory, and adaptive actions. Endocr. Rev. 21, 55-89.

Sauer, J.R., Hines, J.E. \& Fallon, J. (2007). The North American Breeding Bird Survey, results and analysis 19662006. Version 10.13.2007. Laurel, MD: USGS Patuxent Wildlife Research Center. [online] URL: http://www.mbrpwrc.usgs.gov/bbs/bbs2006.html [cited February 2012].

Sherry, T.W. \& Holmes, R.T. (1989). Age-specific social dominance affects habitat use by breeding American redstarts (Setophaga ruticilla): a removal experiment. Behav. Ecol. Sociobiol. 25, 327-333.

Silverin, B. (1986). Corticosterone-binding proteins and behavioral effects of high plasma levels of corticosterone during the breeding period in the pied flycatcher. Gen. Comp. Endocrinol. 64, 67-74.

Silverin, B. (1993). Territorial aggressiveness and its relation to the endocrine system in the pied flycatcher. Gen. Comp. Endocrinol. 89, 206-213.
Silverin, B. (1998a). Behavioral and hormonal responses of the pied flycatcher to environmental stressors. Anim. Behav. 55, 1411-1420.

Silverin, B. (1998b). Territorial behaviour and hormones of pied flycatchers in optimal and suboptimal habitats. Anim. Behav. 56, 811-818.

Walker, B.G., Boersma, P.D. \& Wingfield, J.C. (2006). Habituation of adult magellanic penguins to human visitation as expressed through behavior and corticosterone secretion. Conserv. Biol. 20, 146-154.

Wasser, S.K., Bevis, K., King, G. \& Hanson, E. (1997). Noninvasive physiological measures of disturbance in the northern spotted owl. Conserv. Biol. 11, 1019-1022.

Wilson, C.M. \& Holberton, R.L. (2004). Individual risk versus immediate reproductive success: a basis for latitudinal differences in the adrenocortical response to stress in yellow warblers (Dendroica petechia). Auk 121, 12381249.

Wingfield, J.C., Hegner, R.E., Dufty, A.M., Jr. \& Ball, G.F. (1990). The 'challenge hypothesis': theoretical implications for patterns of testosterone secretion, mating systems, and breeding strategies. Am. Nat. 136, 829-846.

Wingfield, J.C. \& Romero, L.M. (2001). Adrenocortical responses to stress and their modulation in free-living vertebrates. In Handbook of physiology: 211-234. McEwen, B.S. \& Goodman, H.M. (Eds). New York: Oxford University Press.

Wingfield, J.C., Vleck, C.M. \& Moore, M.C. (1992). Seasonal changes of the adrenocortical response to stress in birds of the Sonoran Desert. J. Exp. Zool. 264, 419-428.

Zar, J.H. (1999). Biostatistical analysis. 4th edn. Upper Saddle River, NJ: Prentice-Hall. 